\title{
ТИПОВІ СЛЦДИ ЯК ЕЛЕМЕНТ КРИМННАЛІСТИЧНӦ̈ ХАРАКТЕРИСТИКИ ПОРУШЕНЬ ПРАВИЛ БЕЗПЕКИ ДОРОЖНЬОГО РУХУ АБО ЕКСПЛУАТАЦІї ТРАНСПОРТУ ОСОБАМИ, ЯКІ КЕРУЮТЬ ТРАНСПОРТНИМИ ЗАСОБАМИ
}

\author{
КОВАЛЕНКО Володимир Вікторович - кандидат юридичних наук, доцент, \\ професор кафедри кримінально-правових дисциплін Луганського державного \\ університету внутрішніх справ імені Е. О. Дідоренка \\ orcid.org/0000-0001-5310-2092 \\ УДК 343.98 \\ DOI 10.32782/LAW.UA.2021.2.15
}

Стаття присвячена розгляду слідів як одного з елементів криміналістичної характеристики порушень правил безпеки дорожнього руху або експлуатациї транспорту особами, які керують транспортними засобами.

Доведено, що обстановка на місиі дорожнъо-транспортної пригоди (ДТП) включає різні види матеріальних слідів: сліди кочення $i$ ковзання утворені обертанням коліс, сліди тиснення залишатоться при русі гусеничного транспорту, площинні сліди ковзання - під час перемішення полозів. Окрім того, на матеріальних об'єктах обстановки $i$ суб'єктах подї злочину залишаються сліди інших частин транспортного засобу.

За результатами узагальнення судової практики встановлено, що найбільш типовими слідами кримінального правопорушення, передбаченого ст. 286 КК України є: ушкодження на тілі потерпілого (100\%), у тому иислі на трупі (34,2 \%); сліди речовин біологічного походження (60\%) (кров, лімфа, мозкова рідина, сеча, частини шкіри або інших тканин людини); сліди рук (20 \%) (на частинах транспортних засобів (кермо, важіль перемикання передач тошо)); пошкодження транспортних засобів (94,2%) (у результаті зіткнення транспортних засобів з перешкодами, у т.и. з іншими транспортними засобами, пішоходами, велосипедистами тощо); частини, що відділилися від транспортних засобів (94,2%) (брагменти бампера, решітки радіатора, осколки скла Фар, повторювачів вказівників поворотів, частки лако-ббарбового покриття, розлите пальне, машинне масло, гальмівна рідина, рідина склоомивача, охолоджуюча рідина тощо); сліди ходової частини транспортних засобів (75\%) (иин, гусениць, полоз); пошкодження елементів навколишнъої обстановки (30\%) (відбійників на дорозі, опор ліній електропостачання, дорожніх знаків, будівель та споруд, стовбурів дерев); ідеальні сліди (75\%) (відображення в пам'яті очевидців); сліди-документи (чеки, накладні щзоо проведення ремонту транспортного засобу, протоколи перевірки технічного стану транспортного засобу тощо).

Ключові слова: дорожньо-транспортна пригода, криміналістична методика, криміналістична характеристика, елементи криміналістичної характеристики, типові сліди, матеріальні сліди, ідеальні сліди.

\section{Постановка проблеми}

Одним із ключових елементів криміналістичної характеристики порушень правил безпеки дорожнього руху або експлуатації транспорту особами, які керують транспортними засобами, є типові сліди кримінального правопорушення. Такі сліди є складовою обстановки місця дорожньотранспортної пригоди і становлять залишкові явища, що утворилися до, під час або після настання події, що розслідується (місцезнаходження та положення транспортного засобу, причетного до дорожньої події 


\section{Кримінальне право, кримінальний процес та криміналістика}

вщодо предметів навколішньої обстановки, сліди руху транспортного засобу, розташування і поза трупа на проїжджій частині дороги чи узбіччі тощо. У багатьох випадках зв'язки та відносини таких об'єктів між собою, з навколишнім середовищем і подією, відбиваються неповно i розрізнено. При огляді місця події необхідно з'ясувати роль виявлених об’єктів та слідів, зрозуміти їх зв’ язок з обстановкою місця події. Цю структуру обстановки на місці події складають матеріально фіксовані наслідки злочинної події та супутніх їй явищ. Вони несуть головним чином сліди фінальної фази розвитку дорожньої події, і відбиваються в ній фрагментарно [5, с. 116-118]. Описані елементи обстановки доцільно дослідити окремо, як типові сліди кримінального правопорушення, передбаченого ст. 286 КК України.

\section{Аналіз останніх досліджень i публікацій}

Окремі аспекти досудового розслідування кримінально караних порушень правил дорожнього руху та експлуатації транспортних засобів досліджували В. В. Гаркуша, С. В. Головкін, С. С. Данілін, А. А. Дудніков, I. І. Колесник, А. В. Кофанов, П. С. Ауцюк, В. А. Мисливий, Ю. В. Нагорняк, Ю. І. Осадчий, М. А. Пархомчук, О. С. Ховпун, С. О. Шевцов та інші науковці. Однак, у вітчизняній криміналістичній літературі питання щодо типових слідів, як елемента криміналістичної характеристики досліджуваного делікту, на сьогодні залишаються не достатньо дослідженими або дискусійними.

\section{Мета статті}

Метою статті $\varepsilon$ розкриття ознак типових слідів злочину як елемента криміналістичної характеристики порушень правил безпеки дорожнього руху або експлуатації транспорту особами, які керують транспортними засобами.

\section{Результати дослідження}

Сліди кримінального правопорушення в науковій літературі розглядаються у вузькому та широкому значенні. Сліди у вузькому значенні - це матеріальні утворення, що відбивають зовнішню будову взаємодіючих об'єктів, тобто сліди-копії, які можуть бути об'ємними або площинними. Сліди в широкому значенні - це будь-які зміни в навколишньому середовищі, причинно пов'язані 3 подією злочину. Тому слідами є: а) матеріальні предмети або їх частини (труп, знаряддя злому, недопалок, пляма крові, порція зерна, рідини); б) матеріальні копії (слід пальця, взуття, розрубу, розрізу та ін.). Разом з тим слідами в широкому значенні 6 ідеальні відображення - сліди пам'яті (уявні образи). Вони в інформаційному плані 6 більш ємними і відбивають як увесь об'єкт у цілому, так і його частини. Сліди пам'яті є джерелами вербальної інформації щодо форми і властивостей об'єкта, але вони є суб'єктивними [7, с. 112].

Слідова обстановка на місці дорожньотранспортної пригоди (ДТП) включає різні види матеріальних слідів: сліди кочення i ковзання утворені обертанням коліс, сліди тиснення залишаються при русі гусеничного транспорту, площинні сліди ковзання - під час переміщення полозів. Окрім того, на матеріальних об'єктах обстановки і суб'єктах події злочину залишаються сліди інших частин транспортного засобу. Тому на предметах слідової обстановки ДТП можна виявити:

1) сліди тиснення, ковзання і тертя, нанесені бампером, радіатором, крилом, кутом кузова та іншими виступаючими частинами, дверною ручкою, болтом, заднім мостом та ін.;

2) деталі і частини, що відділилися від транспортного засобу, ручка, шайба, частина болта 3 гайкою, кришка бензобака, осколки фарного скла, відщепи деревини кузова, плями мастила, частки лако-фарбового покриття тощо;

3) сліди вантажу, що транспортується: осип зерна, піску, щебня, хімікатів, цегли тощо;

4) сліди нанесення тілесних ушкоджень: кров, частки тканини, волосся, волокна одягу, супутні предмети (гребінець, складаний ніж, гудзик, окуляри тощо) [7, с. 381].

Механізм дорожньо-транспортної пригоди є стадійним. А. В. Кофанов зі співав- 
торами виділяють такі фази: 1) початкову;2) кульмінаційну і 3) кінцеву.

Для початкової фази ДТП характерними є умови руху транспортного засобу і пішоходів, що склалися перед виникненням небезпечної ситуації, при якій учасники руху повинні негайно вжити всіх можливих заходів для запобігання дорожньотранспортної події і зменшення можливих наслідків. Кульмінаційна фаза ДТП характеризується подіями, що викликають найбільш тяжкі наслідки (пошкодження автомобілів, травми пішоходів, пасажирів, водіїв). Ця фаза протікає швидко (як правило, кілька секунд) і розвивається на ділянці дороги невеликої довжини. Кінцева фаза ДТП нерідко збігається 3 припиненням руху транспортного засобу [6, с. 255]. Чітко диференціювати межі кульмінаційної і кінцевої фаз, як правило, дуже складно.

Слідоутворення зазвичай відбувається в межах двох останніх фаз. Так, у кульмінаційній фазі відбувається контактна взаємодія транспортного засобу 3 іншими транспортними засобами, пішоходами чи нерухомими об'єктами навколишньої обстановки (стовбури дерев, опори ліній електропостачання тощо). Саме у цій фазі утворюється переважна більшість слідів, різновид яких залежить від типу взаємодії. У рамках кінцевої фази, транспортний засіб продовжує залишати в навколишній обстановці певні відображення, аж до моменту зупинки.

Водночас, деякі сліди можуть утворюватися i на початковій стадії дорожньотранспортної пригоди. Зазвичай це сліди гальмування або сліди контактної взаємодії транспортного засобу із об'єктами навколишньої обстановки внаслідок маневрування з метою уникнення аварії.

Склад кримінального правопорушення, передбачений ст. 286 КК України, передбачає, як необхідний для кваліфікації наслідок, заподіяння особі тілесних ушкоджень того чи іншого ступеня тяжкості (аж до настання її смерті). Через це обов'язковим елементом слідової картини порушення правил безпеки дорожнього руху або експлуатації транспорту особами, які керують транспортними засобами, є ушкодження на тілі потерпілого. Ч. 1 названої статті передбачає заподіяння середньої тяжкості тілесного ушкодження, ч. 2 - тяжкого тілесного ушкодження або смерті потерпілого; ч. 3 - смерті двох або більше осіб. У всіх досліджених нами кримінальних провадженнях (100\%) фіксувалися ушкодження на тілі потерпілого як сліди та наслідки дорожньотранспортної пригоди.

За аналогією із описаними науковцями мототравмами [9, с. 155-157], з використанням досліджених нами варіантів механізму події, можна визначити типові пошкодження, яких зазнають жертви ДТП незалежно від типу транспортного засобу:

1. Травма водія чи пасажира від зіткнення 3 іншим рухомим транспортом (вантажним або пасажирським).

2. Травма водія чи пасажира від зіткнення транспортного засобу з нерухомими предметами. Пошкодження учасникам заподіюють деталі транспортного засобу, нерухомих предметів і дороги.

3. Травма пішохода від зіткнення 3 транспортним засобом. Травма від наїзду транспортного засобу на людину характеризується розташуванням пошкоджень, заподіяних ударом транспортного засобу та його деталей на будь-якій $з$ поверхонь тіла, причому пошкодження, викликані первинним ударом, розташовуються на рівнях гомілок і тазу. Локалізація пошкоджень від удару деталями транспортного засобу та контакту 3 дорожнім покриттям дозволяє поділити цей варіант на три підваріанти: зіткнення транспортного засобу 3 людиною при первинному ударі нижче за центр тяжіння тіла людини; зіткнення транспортного засобу з людиною при первинному ударі вище за центр тяжіння тіла людини; зіткнення транспортного засобу 3 людиною при первинному ударі нижче та вторинному - вище за центр тяжіння тіла людини.

4. Травма водія чи пасажира від падіння 3 рухомого мотоцикла, випадання із транспортного засобу.

5. Травма від перекидання транспортного засобу.

6. Травма людини, викликана перекочуванням коліс транспортного засобу. 


\section{Кримінальне право, кримінальний процес та криміналістика}

7. Травми внаслідок горіння чи детонації (вибуху) транспортного засобу.

Аналіз судової практики за фактами порушень правил безпеки дорожнього руху або експлуатації транспорту особами, які керують транспортними засобами у 20192020 роках $^{1}$ дозволив виокремити наступні групи типових слідів кримінального правопорушення.

У 34,2 \% досліджених нами випадків дорожньо-транспортна пригода призвела до смерті потерпілого. Про цьому необхідно оглянути труп на місці його виявлення, зафіксувати пошкодження, сліди транспортного засобу та об'єктів навколишньої обстановки на ньому.

Сліди речовин біологічного походження (60\%). Залишення відповідних речовин на місці події безпосередньо пов'язано із травмуванням потерпілих. Це може бути кров, лімфа, мозкова рідина, сеча, частини шкіри або інших тканин людини. Слідосприймаючими об’єктами виступають предмети навколишньої обстановки, транспортний засіб, який наїхав на пішохода, внутрішні елементи транспортного засобу, у якому перебували постраждалий водій чи пасажир.

Сліди рук (20\%). Сліди рук людини залишаються на частинах транспортних засобів практично у всіх випадках, коли особа ними керує. Утім, фіксація таких відображень не завжди є суттєвою для розслідування порушень правил безпеки дорожнього руху або експлуатації транспорту особами, які керують транспортними засобами. Подібні сліди набувають значення у випадках, коли підозрюваний стверджує, що транспортним засобом керувала інша особа. За слідами на рульовому колесі, важелі перемикання передач та інших елементах управління можна ідентифікувати осіб, які керували транспортним засобом.

Пошкодження транспортних засобів $(94,2 \%)$. Для дорожньо-транспортних пригод типовим є пошкодження транспортних засобів, які взяли участь у механізмі події.

\footnotetext{
${ }^{1}$ Було вивчено 70 вироків судів за фактами порушень правил безпеки дорожнього руху або експлуатації транспорту особами, які керують транспортними засобами ухвалених судами Ауганської та Донецької областей у 2019-2020 роках.
}

У більшості випадків механізм виникнення таких слідів пов'язаний із контактною взаємодією та їі наслідками: зіткнення транспортних засобів, контакт із нерухомою перешкодою, контакт із пішоходом або велосипедистом тощо. Ступінь ушкодження залежить від типу взаємодії та сили удару, яка, у свою чергу, залежить від швидкості руху об'єктів, що вступили в контакт. Відтак, пошкодження на транспортному засобі є цінним джерелом інформації про механізм дорожньо-транспортної пригоди.

Крім того, у результаті ДТП можливе займання транспортних засобів та детонація легкозаймистих речовин, які в них містяться. У таких випадках на транспортних засобах та об'єктах навколишньої обстановки залишаються характерні сліди горіння та вибуху. Зокрема, в одному із досліджених нами кримінальних проваджень $(1,4 \%)$ у результаті зіткнення двох легкових автомобілів відбулося займання та повне знищення вогнем транспортного засобу потерпілого [1].

Також ми облікували один випадок $(1,4 \%)$, коли в результаті вчинення кримінального правопорушення, передбаченого ст. 286 КПК України, транспортний засіб не було пошкоджено. В описаній ситуації водій транспортного засобу здійснив наїзд на людину, яка перебувала в стані алкогольного сп'яніння та знаходилася в горизонтальному положенні на дорожньому полотні, повернута правою боковою поверхнею тіла до автомобіля, що рухався [3]. У той час як на тілі людини утворилися сліди, які відповідають перекочуванню коліс транспортного засобу, сам автомобіль лишився неушкодженим. Ще в одному випадку (1,4\%) транспортний засіб після наїзду на потерпілого, який знаходився у горизонтальному положенні, зіткнувся із нерухомою перешкодою [4], та ушкодження на ньому виникли саме в результаті цієї взаємодії.

У 94,2 \% досліджених випадків у ході огляду місця дорожньо-транспортної події фіксувалися та вилучалися частини транспортних засобів. Подібні сліди утворюються в результаті контактної взаємодії транспортного засобу із тілом людини, іншим транспортним засобом або нерухомою пе- 
решкодою. Через удар від транспортного засобу відділяються його окремі складові частини або деталі (фрагменти бампера, решітки радіатора, осколки скла фар, повторювачів вказівників поворотів, частки лако-фарбового покриття тощо). Уламки пошкодженого транспортного засобу лишаються у навколишній обстановці: на дорозі, на нерухомих перешкодах, на інших транспортних засобах та на тілі потерпілої особи, на яку було здійснено наїзд. Завдяки аналізу таких слідів можна зробити припущення про механізм дорожньо-транспортної події; тип, напрям та силу удару тощо. Залишені на місці події частини транспортного засобу надають можливість звузити коло пошуку та ідентифікувати транспортний засіб, який зник з місця ДТП. Серед цієї групи слідів варто виокремлювати частини транспортного засобу, яким було спричинено ДТП та частини транспортного засобу, водій якого не порушував правила дорожнього руху. Так, наприклад, у результаті зіткнення бокового причепу мотоцикла зі стовбуром дерева у лісосмузі, від мотоцикла було відділено фрагменти повторювача повороту, металевий корпус задньої блок-фари $з$ мотоциклетного крила; від бокового причепу на місці події лишилося колесо [2].

До цієї категорії слідів також можна віднести рідини, які можуть витікати із транспортного засобу в результаті його пошкодження (розлите пальне, машинне масло, гальмівна рідина, рідина склоомивача, охолоджуюча рідина тощо).

Сліди ходової частини транспортних засобів (75 \%). А. П. Шеремет зазначає що сліди транспортних засобів - це матеріально фіксовані відображення окремих частин транспорту, за якими можна встановити ряд обставин кримінального провадження, що відносяться як до самого транспорту, так i до особливостей його експлуатації. Види слідів транспортних засобів поділяють за видами транспорту. Останній буває самохідний та несамохідний. Як перший, так i другий поділяють на колісний, гусеничний та полозний. Колісний залишає сліди кочення, гусеничний - сліди тиснення, полозний - сліди ковзання [8, с. 121]. Об'ємні сліди залишаються в результаті руху транспортного засобу по грунтових дорогах, снігу, піску. На асфальтовому покритті можуть лишатися сліди гальмування, а також сліди нашарування через забарвлення протектора шини мастилом, кров'ю, брудом, іншими речовинами. Слідосприймаючим об'єктом виступає дорожнє покриття, а у випадках перекочування транспортного засобу через потерпілого - його тіло та одяг.

Пошкодження елементів навколишньої обстановки (30%). Такі сліди виникають унаслідок контактної взаємодії транспортного засобу із об'єктами навколишньої обстановки. Подібна взаємодія може бути як основним елементом механізму події ДТП (зіткнення транспортного засобу із перешкодою) так і додатковим (зіткнення транспортного засобу із перешкодою після зіткнення 3 іншим транспортним засобом, або наїзду на пішохода). Пошкоджень, як правило, зазнають відбійники на дорозі, опори ліній електропостачання, дорожні знаки, будівлі та споруди, стовбури дерев.

Ідеальні сліди (75\%). У більшості досліджених випадків кримінально-караних порушень правил дорожнього руху порушення відбувалися в умовах очевидності та залишали ідеальні відображення в пам'яті тих чи інших осіб. Джерелами інформації про кримінальне правопорушення виступали потерпілі (які вижили та знаходяться при тямі) чи свідки-очевидці. 3 метою фіксації ідеальних слідів названі особи допитувалися під час досудового розслідування та у судовому провадженні.

У якості специфічний різновид слідів вчинення кримінального правопорушення, передбаченого ст. 286 КК України, можна виокремити сліди-документи. На наше переконання, до такої категорії документів не доцільно відносити посвідчення водія, свідоцтво про реєстрацію транспортного засобу, поліс обов'язкового страхування цивільно-правової відповідальності автовласників на території України та інші документи, які існують незалежно від дорожньо-транспортної події. Натомість, до такої категорії можуть бути віднесені документи, які посвідчують технічний стан транспортного засобу у випадках, коли 


\section{Кримінальне право, кримінальний процес та криміналістика}

ДТП сталося через наявність тих чи інших технічних несправностей. Це чеки, накладні щодо проведення ремонту транспортного засобу, протоколи перевірки технічного стану транспортного засобу (у випадках, коли технічний контроль є обов'язковим), документи, які посвідчують придбання запасних частин тощо.

\section{Висновки}

Підводячи підсумки, слід зазначити, що найбільш активно слідоутворення відбувається на кульмінаційній та кінцевій фазах дорожньо-транспортної пригоди, але сліди можуть утворюватися і на початковій фазі (наприклад, сліди гальмування). Найбільш типовими слідами кримінального правопорушення, передбаченого ст. 286 КК України, є: ушкодження на тілі потерпілого $(100 \%)$, у тому числі на трупі (34,2 \%); сліди речовин біологічного походження (60\%); сліди рук (20\%); пошкодження транспортних засобів (94,2 \%); частини, що відділилися від транспортних засобів (94,2 \%); сліди ходової частини транспортних засобів $(75 \%)$; пошкодження елементів навколишньої обстановки (30\%); ідеальні сліди (75\%), а також сліди-документи.

Використання зазначених слідів надасть органам досудового розслідування можливості вирішення багатьох ідентифікаційних, діагностичних і ситуаційних завдань щодо встановлення обставин кримінального правопорушення, пов'язаного 3 порушенням правил безпеки дорожнього руху або експлуатації транспорту особами, які керують транспортними засобами.

\section{Мiтература}

1. Вирок Кремінського районного суду Ауганської області у справі № 414/231/20 від 16.07.2020 / Єдиний державний реєстр судових рішень. URL: https://reyestr.court. gov.ua/Review/91573554.

2. Вирок Кремінського районного суду Ауганської області у справі № 414/1477/20 від 07.09.2020 / Єдиний державний реєстр судових рішень. URL: https://reyestr.court. gov.ua/Review/91359810.

3. Вирок Старобільського районного суду Ауганської області у справі-
№ 409/765/18 від 26.06.2020 / Сдиний державний реєстр судових рішень. URL: https://reyestr.court.gov.ua/Review/90062424.

4. Вирок Сватівського районного суду Ауганської області у справі № 426/5156/20 від 22.07.2020 / Єдиний державний реєстр судових рішень. URL: https://reyestr.court. gov.ua/Review/90563503.

5. Ермолович В. Ф. Криминалистическая характеристика преступлений. Минск: Амалфея, 2001. 287 с.

6. Кофанов А. В., Кобилянський О. А., Кузьмічов Я. В. та ін. Криміналістика: питання і відповіді. Навч. посіб. Київ : Центр учбової літератури, 2011. 280 с.

7. Салтевський М. В. Криміналістика. Підручник: У 2-х ч. Ч. 1. Харків, 1999. $416 \mathrm{c}$.

8. Шеремет А. П. Криміналістика: навч. пос. для студ. вищ. навч. закл. 2-ге вид. Київ, 2009. 472 с.

9. Шевцов С. О., Дубонос К. В. Расследование обстоятельств дорожнотранспортных происшествий: метод рек. Харьков: Факт, 2002. 172 с.

Kovalenko Volodymyr Viktorovych - PhD in Law, Associate Professor, Professor in the Chair of Criminal-Law Disciplines of Luhansk State University of Internal Affairs named after E. Didorenko orcid.org/0000-0001-5310-2092 UDK 343.98

TYPICAL TRACES AS AN ELEMENT OF FORENSIC CHARACTERISTICS OF VIOLATIONS OF TRAFFIC SAFETY RULES OR VEHICLE OPERATION BY THE PERSONS WHO DRIVE VEHICLES

The article is devoted to the study of traces as one of the elements of forensic characteristics of violations of traffic safety rules or vehicle operation by the persons who drive vehicles.

It is proved that the situation at the scene of a traffic accident includes different types of material traces: rolling and sliding traces formed by the rotation of the wheels, embossing traces of caterpillar vehicles movement, planar sliding traces - during the movement of skids. In addition, traces of other parts of 
the vehicle remain on the material objects of the situation and the subjects of the crime.

According to the results of generalization of judicial practice, it is established that the most typical traces of a criminal offense under Art. 286 of the Criminal Code of Ukraine are: injuries on the body of the victim $(100 \%)$, including the corpse (34.2\%); traces of substances of biological origin $(60 \%)$ (blood, lymph, cerebrospinal fluid, urine, parts of skin or other human tissues); handprints (20\%) (on vehicle parts (steering wheel, gear lever, etc.)); damage to vehicles (94.2\%) (as a result of collision of vehicles with obstacles, including other vehicles, pedestrians, cyclists, etc.); parts separated from vehicles (94.2\%) (bumper fragments, radiator grilles, broken glass headlights, turn signal repeaters, paintwork particles, spilled fuel, engine oil, brake fluid, windshield washer fluid, coolant, etc.); traces of the chassis of vehicles $(75 \%)$ (tires, tracks, skids); damage to the elements of the environment (30\%) (road bumpers, power lines, road signs, buildings and structures, tree trunks); traces of memory $(75 \%)$ (reflected in the memory of eyewitnesses); document traces (checks, invoices for vehicle repairs, protocols for checking the technical condition of the vehicle, etc.).

Key words: traffic accident, forensic methodology, forensic characteristics, elements of forensic characteristics, typical traces, material traces; perfect tracks. 